\title{
Association between gene polymorphism of CD14-159 (C/T) and allergic asthma
}

\author{
SONG-QUAN WU ${ }^{1}$, KAI-BO ZHANG ${ }^{1}$, HAI-QUAN CHEN ${ }^{2}$, \\ ZHI-GANG ZHAO ${ }^{2}$, GUANG-LI WANG ${ }^{1}$ and CONG CHEN ${ }^{1}$ \\ ${ }^{1}$ Medical Department of Lishui University; ${ }^{2}$ Central Hospital of Lishui City, Lishui, Zhejiang 323000, P.R. China
}

Received May 12, 2011; Accepted August 11, 2011

DOI: $10.3892 / \mathrm{mmr} .2011 .554$

\begin{abstract}
The objective of this study was to evaluate the possible association between the CD14-159 polymorphism and adult asthma in the Chinese population. A total of 188 asthmatic patients and 60 healthy adults were enrolled in the present study, and the CD14-159 polymorphism was genotyped using the polymerase chain reaction-restriction fragment length polymorphism (PCR-RFLP) analysis. The results showed that the frequencies of $\mathrm{CC}$, CT and TT genotypes were $12.2,47.9$, and $39.9 \%$, respectively, in the asthma group, and 8.3, 50.0, and 41.7\%, respectively, in healthy adults, with no statistical difference between the two groups $(\mathrm{P}>0.05)$. The frequencies of $\mathrm{C}$ and $\mathrm{T}$ allele were 36.2 and $63.8 \%$, respectively, in the asthma group, 33.3 and $66.7 \%$, respectively, in the healthy group, and no statistical difference was observed in the allele frequencies between the two groups $(\mathrm{P}>0.05)$. Our data suggest that the CD14-159 polymorphism is not associated with adult asthma in Chinese population.
\end{abstract}

\section{Introduction}

CD14 is expressed either on the surface of monocytes, macrophages and neutrophils, or may present in a soluble form in serum (1). Binding of CD14 to lipopolysaccharide (LPS) promotes the secretion of IL-12, which is an essential signal for differentiation and maturation of naïve T cells in Th1 cells (2).

Therefore, changes in the expression of CD14 affect the ratio of Th1 to Th2, thereby reducing $\operatorname{IgE}$ production $(3,4)$. A functional single nucleotide polymorphism (C-159T) has been found in the promoter region of the CD14 gene, and this polymorphism is associated with the changes of CD14 and IgE levels in different ethnic groups (5-7). CD14 expression is up-regulated in asthma patients following stimulation with

Correspondence to: Dr Song-quan Wu, Medical Department of Lishui University, Xueyuan Road, Lishui, Zhejiang 323000, P.R. China

E-mail: wusq20100429@126.com

Key words: asthma, CD14, genetic polymorphism allergens and inhalation of LPS (3-7). In the present study, we characterized the genotypes of the CD14-159T gene polymorphism in adult asthma patients using polymerase chain reaction-restriction fragment length polymorphism (PCR-RFLP) analysis in an attempt to determine the possible association of the CD14-159 polymorphism with asthma or asthma severity.

\section{Patients and methods}

Patients. A total of 188 asthma patients diagnosed in the Central Hospital of Lishui City, China, between October 2008 and October 2010, were assigned to the asthma group: 100 males and 88 females participated, aged 18-76 years, with an average age of 45.3 years. Diagnosis of asthma was established according to the criteria in 'Practical internal medicine' by Haozhu Chen (8). According to the grading standards for asthma, we identified 24 cases with intermittent asthma (grade I), 76 cases with mild persistent asthma (grade II), 68 cases with moderate persistent asthma (grade III), and 20 cases with severe persistent asthma (grade IV). The control group included 60 healthy adults aged 18-67 years with an average age of 43.1 years. These controls, including 36 males and 24 females, were randomly selected healthy volunteers without any personal or family history of atopy. They had no respiratory tract infections in the last month prior to enrolment, and had received no steroids or antihistamines in the last six months. Signed consent was obtained from all subjects. This study was approved by the Ethics Committee of the Medical Department of Lishui College, China.

Reagents. Reagents for PCR-RFLP, including TaqDNA polymerase, dNTP and DNA molecular weight markers, were purchased from Takara (Dalian, China). AvaII restriction enzyme was obtained from Promega (Madison, WI, USA).

Genomic DNA extraction. A total of $3 \mathrm{ml}$ of peripheral venous blood was collected from asthma patients. Following anticoagulation with heparin, leucocytes were isolated and whole-genome DNA was extracted using a QiaAmp DNA blood mini kit (Qiagen, Valencia, CA, USA) according to the manufacturer's instructions. Isolated DNA samples were then stored at $-20^{\circ} \mathrm{C}$. Genomic DNA extraction from the control group followed the same procedures. 


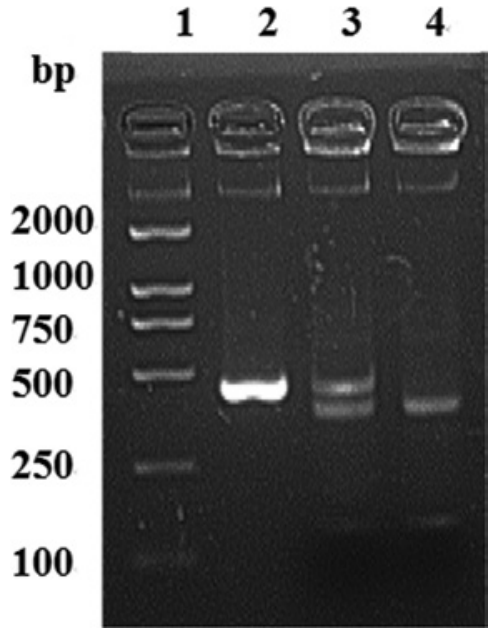

Figure 1. Agarose gel electrophoresis analysis of CD14 genotypes cleaved by AvaII enzyme. Note: Lane 1, DL2000 marker; Lane 2, wild-type genotype (C/C); Lane 3, heterozygous mutant genotype (C/T); Lane 4, homozygous mutant genotype (T/T)
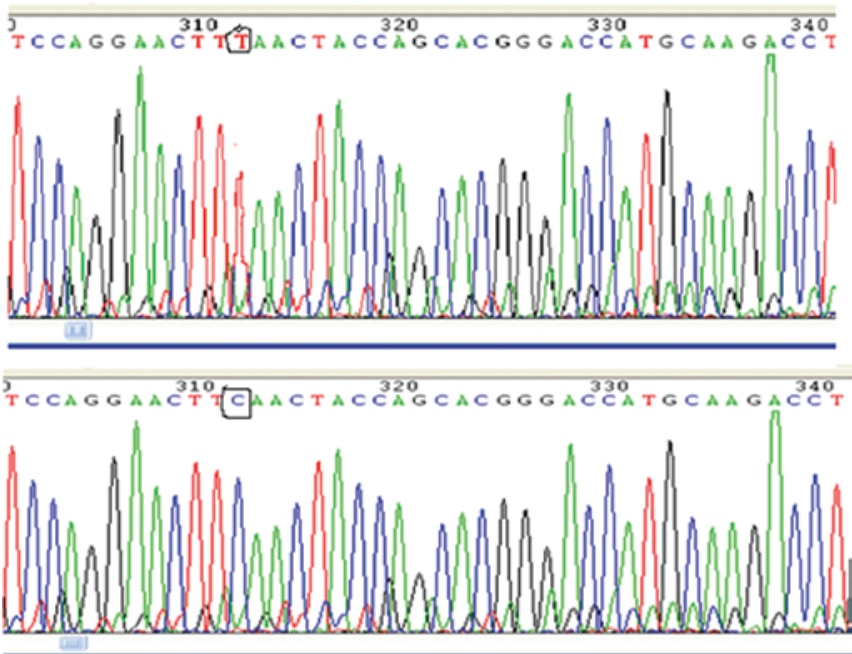

Figure 2. Gene sequencing results for CTTCAA (wild-type CC genotype) and CTTTAA (mutant TT genotype).

Table I. CD14 C-159T genotype and allele frequencies in adult asthma patients.

\begin{tabular}{|c|c|c|c|c|c|c|c|}
\hline \multirow[b]{2}{*}{ Group } & \multirow[b]{2}{*}{$\begin{array}{c}\text { Subgroup } \\
\text { (Grade) }\end{array}$} & \multirow[b]{2}{*}{$\mathrm{n}$} & \multicolumn{3}{|c|}{ Genotype frequency $(\%)^{\mathrm{a}}$} & \multicolumn{2}{|c|}{ Allele frequency $(\%)^{\mathrm{b}}$} \\
\hline & & & $\mathrm{CC}$ & $\mathrm{CT}$ & TT & $\mathrm{C}$ & $\mathrm{T}$ \\
\hline \multirow{4}{*}{ Asthma group } & I & 24 & $3(12.5)$ & $11(45.8)$ & $10(41.7)$ & 35.4 & 64.6 \\
\hline & II & 76 & $10(13.2)$ & $37(48.7)$ & $28(38.2)$ & 37.5 & 62.5 \\
\hline & III & 68 & 8 (11.8) & $32(47.1)$ & $28(41.2)$ & 35.3 & 64.7 \\
\hline & IV & 20 & $2(10.0)$ & $10(50.0)$ & $8(40.0)$ & 35.0 & 65.0 \\
\hline Sub-total & & 188 & $23(12.2)$ & $90(47.9)$ & $75(39.9)$ & 36.2 & 63.8 \\
\hline Control group & & 60 & $5(8.3)$ & $30(50.0)$ & $25(41.7)$ & 33.3 & 66.7 \\
\hline Total & & 248 & $28(11.3)$ & $120(48.4)$ & $100(40.3)$ & 35.5 & 64.5 \\
\hline
\end{tabular}

Group, ${ }^{\mathrm{a}} \chi^{2}=0.691(\mathrm{P}=0.708)$ and ${ }^{\mathrm{b}} \chi^{2}=0.320(\mathrm{P}=0.572)$; subgroup, ${ }^{\mathrm{a}} \chi^{2}=1.014(\mathrm{P}=0.998)$ and ${ }^{\mathrm{b}} \chi^{2}=0.519(\mathrm{P}=0.972)$.

PCR amplification. The primers, previously described (4) and synthesized by Takara (China), used were: forward 5'-GTGCCAACAGATGAGGTTCAC-3' and reverse 5'-GCC TCTGACAGTTTTATGTAATC-3'. The PCR reaction was performed in a total volume of $50 \mu \mathrm{l}$ containing $5 \mu \mathrm{l}$ of 10X buffer $\left(15 \mathrm{mM} \mathrm{MgCl}_{2}\right), 4 \mu \mathrm{l}$ of $\mathrm{dNTP}(200 \mu \mathrm{mnol} / \mathrm{l})$, $1 \mu \mathrm{l}$ of each primer $(25 \mathrm{pmol} / \mu \mathrm{l}), 0.5 \mu \mathrm{l}$ of TaqDNA polymerase $(5 \mathrm{U} / \mu \mathrm{l}), 4 \mu \mathrm{l}$ of DNA template, and sufficiently distilled water to a final volume of $50 \mu \mathrm{l}$. PCR amplification was performed at an initial denaturation step at $94^{\circ} \mathrm{C}$ for $5 \mathrm{~min}$, followed by 35 cycles consisting of $94^{\circ} \mathrm{C}$ for $30 \mathrm{sec}, 64^{\circ} \mathrm{C}$ for $30 \mathrm{sec}$ and $72^{\circ} \mathrm{C}$ for $1 \mathrm{~min}$, and a final extension step at $72^{\circ} \mathrm{C}$ for $10 \mathrm{~min}$. After amplification, PCR products were separated by $2 \%$ agarose gel containing $0.5 \mathrm{mg} / \mathrm{ml}$ ethidium bromide (EB) electrophoresis.

PCR-RFLP. A total of $10 \mu 1$ of each PCR amplification product was digested by AvaII in $10 \mathrm{x}$ restriction buffer with $\mathrm{MgCl}_{2}$, bovine serum albumin $(1 \mu \mathrm{g} / \mu \mathrm{l})$ (Promega, Madison, WI, USA) and 1 unit AvaII (Promega) and sterile water to a final volume of $20 \mu \mathrm{l}$. Digestion was carried out in a water bath at $37^{\circ} \mathrm{C}$ for $3 \mathrm{~h}$. After restriction digestion, restricted products were subject to $2 \%$ agarose gel (containing EB) electrophoresis. Subsequently, genotypes were analyzed in a gel image analysis system. Bands with appropriate sizes showing different genotypes were as follows: CC: (497 bp), CT (497, 353, and 144 bp), TT (353 and 144 bp).

Gene sequencing. Each randomly selected sample of PCR products identified to harbor the CC or TT genotype by RFLP analysis was sent to Shanghai Sangon Biological Engineering Technology and Services Co., Ltd for purification and sequencing.

Statistical analysis. Genotype and allele frequencies in the asthma and control groups were calculated using the gene counting method. After being tested using the Hardy-Weinberg equilibrium, the data were analyzed by the statistical software 
SPSS version 12.0. Genotype and allele frequencies in the two groups were tested using the $\chi^{2}$ test.

\section{Results}

PCR products and results of Avall digestion. The PCR product was $497 \mathrm{bp}$ in length (Fig. 1). When a wild-type cytosine nucleotide was present at position 159 in the CD14 gene, AvaII was not able to cleave this gene and therefore generated a fragment of 497 bp alone (CC genotype). In contrast, when the position 159 contained a mutant thymine nucleotide, AvaII cleaved the CD14 gene into two fragments with 353 and $144 \mathrm{bp}$, respectively (TT genotype). Similarly, the heterozygous genotype (CT genotype) generated three fragments of 497, 353 and 144 bp, respectively (Fig. 1).

Hardy-Weinberg genetic equilibrium test. The CD14 genotypes in the asthma and control groups were subject to the Hardy-Weinberg genetic equilibrium test. The genotypes of the two groups were in Hardy-Weinberg genetic equilibrium, suggesting a good genetic representation of the source population $(\mathrm{P}>0.05)$.

Comparison of CD14-159 genotype and allele frequencies between the asthma and control groups. The frequencies of the three genotypes CC, CT and TT were 12.2, 47.9 and $39.9 \%$, respectively, in the asthma group and 8.3, 50.0 and $41.7 \%$, respectively, in the control group. No statistical difference of genotype distribution between the two groups was observed $(\mathrm{P}>0.5)$. The $\mathrm{C}$ and $\mathrm{T}$ allele frequencies were 36.2 and $63.8 \%$, respectively, in the asthma group and 33.3 and $66.7 \%$, respectively, in the control group. No significant difference was found between the two groups $(\mathrm{P}>0.5$, Table I).

Gene sequencing. Following gene sequencing, the obtained DNA sequences were compared with the human CD14-159 gene sequences retrieved from GenBank database. Comparison results were confirmed by gene sequencing as shown in Fig. 2 .

\section{Discussion}

CD14 gene is mapped to $5 \mathrm{q} 31$, a region shown to be linked to Th2 cell functions and responsible for the increase of serum IgE levels in different populations (8). Various studies have addressed the polymorphisms of the CD14 gene, and the $\mathrm{C}-159 \mathrm{~T}$ gene polymorphism localized in the promoter region of the CD14 gene is most closely related to allergic diseases $(10,11)$. The In vitro transient transfection of monocytes with the CD14 gene demonstrates that the C-159T gene polymorphism increases $\mathrm{CD} 14$ transcription by lowering the affinity of CD14 regulatory regions to $\mathrm{Sp3}$, a factor known to inhibit the activity in most promoters (12). Additionally, the C-159T TT genotype is also associated with the elevation of sCD14 in circulation $(10,11)$. A low level of sCD14 means a low number of positive skin tests and a reduced level of serum IgE, which is linked to non-allergic asthma and food allergy in different ethnic groups $(5,10,11)$. Conversely, the CC genotype increases serum IgE levels and the number of positive skin tests $(5,10,11)$. Therefore, the $\mathrm{C}$ allele is associated with allergy.
The $\mathrm{C}-159 \mathrm{~T}$ gene polymorphism in the allergic mechanisms may be age-related (13). At present, the correlation between an increased expression of CD14 and the C-159T gene polymorphism has only been found in the serum of children, but not in that of adults (13). Furthermore, the CC genotype is only associated with early allergic reactions and early airway hyperresponsiveness in individuals aged 8-25 years. Therefore, allergic reactions to the $-159 \mathrm{C}$ genotype were also found to be age-specific (13).

Studies have also shown that the associations between the C-159T gene polymorphism and allergy are not always consistent (14-16). For example, the gene polymorphism in the CD14 gene was associated with elevated levels of soluble CD14, but not with IgE or allergic diseases, including bronchial asthma (14-16). Notably, a high degree of linkage disequilibrium in the CD14 promoter region has offered an explanation for the association of CD14, or other genes on chromosome 5q, including the C-159T polymorphism with asthma (17). Presumably, the over-expression of the CD14-159T allele expressed in Spanish and Portuguese individuals with near relations may be due to the presence of linkage disequilibrium of the CD14-159T allele in the mutant chromosome 5q (18). However, whether or not an association between the C-159T gene polymorphism and allergy in different ethnic populations exists, may depend on environmental factors $(5,10,11)$.

Allergic asthma is an IgE-mediated type I allergic disease characterized by pulmonary eosinophil accumulation, excessive mucus secretion and airway hyperresponsiveness. No study has as yet reported the association of the C-159T gene polymorphism with allergic asthma. The present study found that the CD14-159 gene polymorphism was not associated with asthmatic adults and asthma severity. Although the CD14C-159T gene polymorphism may regulate airway remodeling in asthma, it is likely that separate genes on chromosome 5q may regulate total serum IgE levels and bronchial airway responsiveness.

\section{References}

1. Marcos V, Latzin P, Hector A, Sonanini S, Hoffmann F, Lacher M, Koller B, Bufler P, Nicolai T, Hartl D and Griese M: Expression, regulation and clinical significance of soluble and membrane CD14 receptors in pediatric inflammatory lung diseases. Respir Res 19: 32-34, 2010.

2. Chen Y, Yang C, Jin N, Xie Z, Fei L, Jia Z and Wu Y: Sinomenine promotes differentiation but impedes maturation and co-stimulatory molecule expression of human monocyte-derived dendritic cells. Int Immunopharmacol 7: 1102-1110, 2007.

3. Martinez FD: CD14, endotoxin, and asthma risk: actions and interactions. Proc Am Thorac Soc 4: 221-225, 2007.

4. Jackola DR, Basu S, Liebeler CL, Willaert R, Luah SS, Oetting W, King RA and Blumenthal MN: CD14 promoter polymorphisms in atopic families: implications for modulated allergen-specific immunoglobulin E and G1 responses. Int Arch Allergy Immunol 139: 217-224, 2006.

5. Zhang G, Goldblatt J and Lesoëf PN: Does the relationship between IgE and the CD14 gene depend on ethnicity. Allergy 63: 1411-1417, 2008.

6. Zhou H, Alexis NE, Almond M, Donohue J, Laforce C, Bromberg PA and Peden DB: Influence of C-159T SNP of the CD14 gene promoter on lung function in smokers. Respir Med 103: 1358-1365, 2009.

7. Keskin O, Birben E, Sackesen C, Soyer OU, Alyamac E, Karaaslan C, Tokol N, Ercan H and Kalayci O: The effect of CD14-C159T genotypes on the cytokine response to endoxin by peripheral blood mononuclear cells from asthmatic children. Ann Allergy Asthma Immunol 97: 321-328, 2006. 
8. Chen H: Practical internal medicine. People's Health Press, Beijing: 1997, pp1397-1404.

9. Ryu HJ, Jung HY, Park JS, et al: Gene-based single nucleotide polymorphisms and linkage disequilibrium patterns of 29 asthma candidate genes in the chromosome 5q31-33 region in Koreans. Int Arch Allergy Immunol 139: 209-216, 2006.

10. Leung TF, Tang NL, Sung YM, Li AM, Wong GW, Chan IH and Lam CW: The C-159T polymorphism in the CD14 promoter is associated with serum total $\mathrm{IgE}$ concentration in atopic Chinese children. Pediatr Allergy Immunol 14: 255-260, 2003.

11. Han D, She W and Zhang L: Association of the CD14 gene polymorphism C-159T with allergic rhinitis. Am J Rhinol Allergy 24: e1-3, 2010.

12. Liu S, Shapiro RA, Nie S, Zhu D, Vodovotz Y and Billiar TR: Characterization of rat $\mathrm{CD} 14$ promoter and its regulation by transcription factors AP1 and Sp family proteins in hepatocytes. Gene 250: 137-147, 2000.

13. O'Donnell AR, Toelle BG, Marks GB, Hayden CM, Laing IA Peat JK, Goldblatt J and Le Souëf PN: Age-specific relationship between CD14 and atopy in a cohort assessed from age eight to twenty-five. Am J Respir Crit Care Med 169: 615-622, 2003.
14. Kabesch M, Hasemann K, Schickinger V, Tzotcheva I, Bohnert A, Carr D, Baldini M, Hackstein H, Leupold W, Weiland SK, Martinez FD, Mutius E and Bein G: A promoter polymorphism in the CD14 gene is associated with elevated levels of soluble CD14 but not with IgE or atopic diseases. Allergy 59: 52-525, 2004.

15. Kadda MA, Lose F, Duffy D, Bell E, Thompson PJ and Upham J: The CD14 C-159T polymorphism is not associated with asthma or asthma severity in an Australian adult population. Thorax 60: 211-214, 2005.

16. Heinzmann A, Dietrich H, Jerkic SP, Kurz $T$ and Deichmann KA: Promoter polymorphisms of the CD14 gene are not associated with bronchial asthma in Caucasian children. Eur J Immunogenet 30: 345-348, 2003.

17. Vercelli D, Baldini $M$ and Martinez F: The monocyte/IgE connection: may polymorphisms in the CD14 gene teach us about IgE regulation? Int Arch Allergy Immunol 124: 20-24, 2001.

18. Ober C, Tsalenko A, Parry R and Cox NJ: A second-generation genomewide screen for asthma-susceptibility alleles in a founder population. Am J Hum Genet 67: 1154-1162, 2000. 